\title{
Barrel Pattern Formation Requires Serotonin Uptake by Thalamocortical Afferents, and Not Vesicular Monoamine Release
}

\author{
Antonio M. Persico, ${ }^{1}$ Elisa Mengual, ${ }^{2}$ Rainald Moessner, ${ }^{3}$ Scott F. Hall, ${ }^{4}$ Randal S. Revay, ${ }^{4}$ Ichiro Sora, ${ }^{4}$ \\ Jon Arellano, ${ }^{5}$ Javier DeFelipe, ${ }^{5}$ José Manuel Giménez-Amaya, ${ }^{2}$ Monica Conciatori, ${ }^{1}$ Ramona Marino, ${ }^{1}$ \\ Alfonso Baldi, ${ }^{1}$ Simona Cabib, ${ }^{6}$ Tiziana Pascucci, ${ }^{6}$ George R. Uhl, ${ }^{4}$ Dennis L. Murphy, ${ }^{7}$ K. Peter Lesch, ${ }^{3}$ and \\ Flavio Keller ${ }^{1}$
}

1Laboratory of Neuroscience, Università "Campus Bio-Medico," 00155 Rome, Italy, ${ }^{2}$ Departamento de Anatomia, Facultad de Medicina, Universidad de Navarra, 31008 Pamplona, Spain, ${ }^{3}$ Department of Psychiatry, University of Wuerzburg, 97080 Wuerzburg, Germany, ${ }^{4}$ Molecular Neurobiology Branch, Intramural Research Program/National Institute on Drug Abuse/National Institutes of Health, Baltimore, Maryland 21224, 5/nstituto Cajal, Consejo Superior de Investigación Cientifica, 28029 Madrid, Spain, 'Department of Psychology, Università "La Sapienza," 00185 Rome, Italy, and ${ }^{7}$ Laboratory of Clinical Science, National Institute of Mental Health/National Institutes of Health, Bethesda, Maryland 20892

Thalamocortical neurons innervating the barrel cortex in neonatal rodents transiently store serotonin $(5-\mathrm{HT})$ in synaptic vesicles by expressing the plasma membrane serotonin transporter (5-HTT) and the vesicular monoamine transporter (VMAT2). 5-HTT knock-out (ko) mice reveal a nearly complete absence of 5-HT in the cerebral cortex by immunohistochemistry, and of barrels, both at P7 and adulthood. Quantitative electron microscopy reveals that 5-HTT ko affects neither the density of synapses nor the length of synaptic contacts in layer IV. VMAT2 ko mice, completely lacking activity-dependent ve- sicular release of monoamines including $5-\mathrm{HT}$, also show a complete lack of 5-HT in the cortex but display largely normal barrel fields, despite sometimes markedly reduced postnatal growth. Transient 5-HTT expression is thus required for barrel pattern formation, whereas activity-dependent vesicular 5-HT release is not.

Key words: barrel; homologous recombination; knock-out; monoamine; p-chlorophenylalanine; serotonin; serotonin transporter; vesicular monoamine transporter; GABA transporter; whisker
Serotonin (5-HT) is known to promote synaptic growth in invertebrates (Glanzman et al., 1990; Bailey et al., 1992). More recent evidence supports a morphogenetic role of 5-HT also in mammalian neocortical development (for review, see Levitt et al., 1997). Brain 5-HT content and 5-HT synthesis capacity display prominent developmental changes in rhesus monkeys (GoldmanRakic and Brown, 1982) and humans (Chugani et al., 1999). The rodent somatosensory cortex lends itself to assessments of 5-HT roles in neocortical development and plasticity, because of its one-to-one correspondence between each whisker on the snout of the animal and its barrel-like representation in the somatosensory cortex (for review, see Killackey et al., 1995; Rice, 1995). Pharmacologically induced 5-HT depletion at birth yields smaller barrels, but does not prevent the formation of the barrel pattern itself (Blue et al., 1991; Bennett-Clarke et al., 1994b; OsterheldHaas et al., 1994). Instead, excess of extracellular 5-HT in monoamine oxidase (MAO)-A knock-out (ko) mice results in the

\footnotetext{
Received Jan. 22, 2001; revised May 29, 2001; accepted June 4, 2001.

This work was funded by the European Community Biomed Program (Grant BMH4-CT96-0730), Fondation Jerôme Lejeune, Fondazione Carisal, the German Federal Ministry for Education and Science (BMBF) (Grant 01 KS 9603), and the Deutsche Forschungsgemeinschaft (Grant Le 629/3-2). K.P.L. is supported by the Hermann and Lilly Schilling Foundation. We thank Dietmar Bengel, Stefano Puglisi-Allegra, and Rossella Ventura for their collaboration, Luigi Carnevali for printing the photomicrographs, and Riccardo Adriani for editorial assistance.

Correspondence should be addressed to Dr. Flavio Keller, Laboratory of Neuroscience, Università "Campus Bio-Medico," Via Longoni 83, I-00155 Rome, Italy. E-mail: f.keller@unicampus.it.

I. Sora's present address: Department of Molecular Psychiatry, Tokyo Institute of Psychiatry, 2-1-8 Kamikitazawa, Setagaya-ku, Tokyo 156-8585, Japan.

Copyright (C) 2001 Society for Neuroscience $0270-6474 / 01 / 216862-12 \$ 15.00 / 0$
}

complete absence of cortical barrel patterns, as shown by Nissl or cytochrome oxidase $(\mathrm{CO})$ staining. The barrel pattern is restored by systemic administration of the selective tryptophanhydroxylase inhibitor $p$-chlorophenylalanine (PCPA) (Cases et al., 1996).

Additional evidence for 5-HT involvement in the development of neonatal rodent somatosensory cortex comes from the transient barrel-like distribution of 5-HT (Fujimiya et al., 1986; D'Amato et al., 1987; Rhoades et al., 1990; Blue et al., 1991; Bennett-Clarke et al., 1991, 1994a; Dori et al., 1996), of 5-HT and 5- $\mathrm{HT}_{2 \mathrm{~A}}$ receptors (Leslie et al., 1992; Bennett-Clarke et al., 1993; Mansour-Robaey et al., 1998), and of the 5-HT transporter (D'Amato et al., 1987; for review, see Fuchs, 1995; Lebrand et al., 1996; Mansour-Robaey et al., 1998). The transient barrel-like 5-HT pattern visualized in layer IV of the somatosensory cortex of neonatal rodents apparently stems from 5-HT uptake and vesicular storage in thalamocortical neurons, which surprisingly express both the plasma membrane serotonin transporter (5HTT) and the vesicular monoamine transporter (VMAT2) at this developmental stage (Lebrand et al., 1996). Thus both 5-HTT and VMAT2 could potentially contribute to the formation or maintenance of the barrel pattern.

Targeted gene inactivation based on homologous recombination has recently provided mice devoid of 5-HTT (Bengel et al., 1998) and VMAT2 (Takahashi et al., 1997; Wang et al., 1997) function. According to recent in vivo microdialysis experiments, 5-HTT ko mice display 14-fold higher extracellular striatal 5-HT concentrations compared with wt littermates (Mathews et al., 

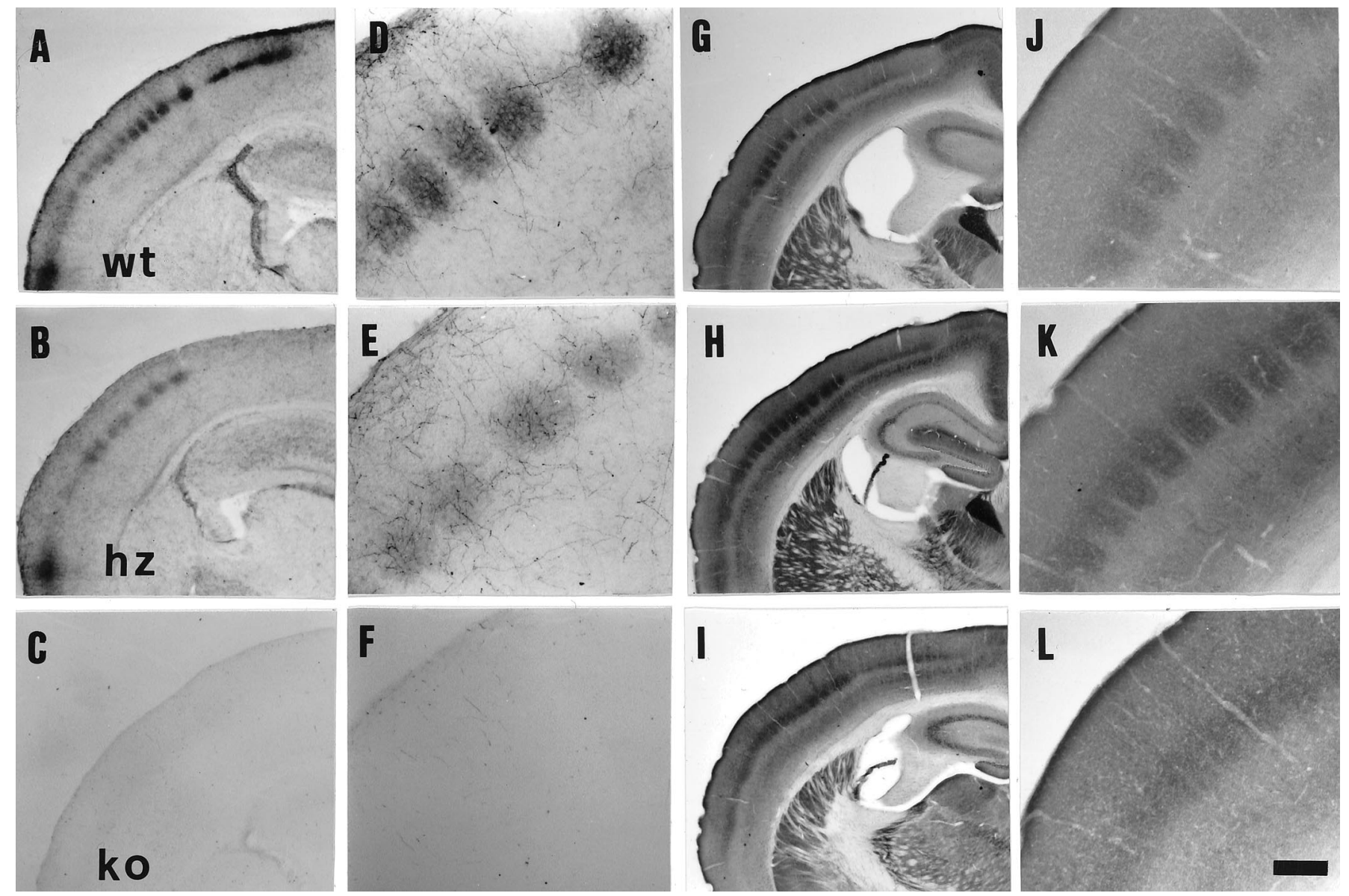

Figure 1. Somatosensory cortical barrels in coronal sections of brains of 5-HTT wt $(A, D, G, J)$, hz $(B, E, H, K)$, and ko $(C, F, I, L)$ mice. $A-C, 5$-HT immunocytochemistry of P7 mouse brains. Notice the reduction and the nearly complete absence of 5-HT immunostaining in 5-HTT hz and ko mice, respectively. $D-F$, Higher magnifications of sections shown in $A-C$; only sparse 5-HT-stained fibers are visible in the cortex of 5-HTT ko mice ( $F)$. $G-I$, $\mathrm{CO}$ staining in coronal sections of adult mouse brains, $4-5$ months old, at the level of the primary somatosensory cortex. $J-L$, Higher magnifications of sections shown in $G-I$. Barrels and septa appear normal in wt and hz animals $(J, K)$, whereas the barrel pattern is nearly absent in 5-HTT ko mice ( $L$ ). Scale bar (shown in $L$ ): $A-C, 560 \mu \mathrm{m} ; D-F, 240 \mu \mathrm{m} ; G-I, 800 \mu \mathrm{m} ; J-L, 250 \mu \mathrm{m}$.

2000). VMAT2 hz and ko mice have $50 \%$ reductions and the complete absence of vesicular monoamine release, respectively (Wang et al., 1997). In this study, we assess 5-HTT and VMAT2 ko animals in parallel, to distinguish whether maintenance of low extracellular 5-HT concentrations by 5-HTT-mediated uptake into thalamocortical endings is a permissive factor in cortical barrel formation or, alternatively, whether discrete patches of high extracellular 5-HT concentration produced by localized vesicular 5-HT release from thalamocortical terminals act as an instructive factor in barrel formation.

\section{MATERIALS AND METHODS}

Animals. VMAT2 and 5-HTT gene inactivation was obtained through homologous recombination, as described (Takahashi et al., 1997; Bengel et al., 1998). F2 homozygous (ko), heterozygous (hz), and wild-type (wt) offspring with C57BL/6J genetic background were used for both 5-HTT and VMAT2 studies. Animal housing and experiments were in accordance with the Italian and European Union regulations. All experiments were performed according to protocol code K3/98 approved by the Italian Ministry of Health (D.L. 116/92).

VMAT2 genotypic status was assessed by Southern blot analysis, as described (Takahashi et al., 1997); 5-HTT genotypes were assessed by PCR using primers upstream (5'-TCTATGGGAAGGCTGACAGGT$\left.3^{\prime}\right)$, downstream (5'-TTGCTGACTGGAGTACAGGCTA-3'), and neo (5'-TCGACGTTGTCACTGAAGCGG-3'), yielding a $1.4 \mathrm{~kb}$ fragment in wt alleles and a $1.1 \mathrm{~kb}$ neo fragment in ko alleles after amplification performed in a $25 \mu \mathrm{l}$ volume containing $50 \mathrm{ng}$ of genomic DNA, $200 \mu \mathrm{M}$ dNTPs, $20 \mathrm{pm}$ of each primer, $1.5 \mathrm{mM} \mathrm{MgCl}_{2}, 1 \times$ PCR buffer, and $2 \mathrm{U}$ of Taq polymerase (PCR reagents by Appligene Oncor, Gaithersburg, $\mathrm{MD})$. Fragments were amplified by initial denaturation at $95^{\circ} \mathrm{C}(5 \mathrm{~min})$, followed by 35 cycles at $94^{\circ} \mathrm{C}(30 \mathrm{sec}), 60^{\circ} \mathrm{C}(30 \mathrm{sec})$, and $72^{\circ} \mathrm{C}(90 \mathrm{sec})$, and by a final extension at $72^{\circ} \mathrm{C}(5 \mathrm{~min})$. $\mathrm{P} 0$ here corresponds to the first $24 \mathrm{hr}$ after birth. A total of 10 5-HTT ko, $12 \mathrm{hz}$, and $12 \mathrm{wt}$ mice were killed at P7, whereas 18 5-HTT ko, $14 \mathrm{hz}$, and $16 \mathrm{wt}$ mice were killed at 4-5 months of age (see Table 1 ). The selective tryptophan-hydroxylase inhibitor PCPA (300 mg/kg) (Koe and Weissman, 1966) was administered subcutaneously to 22 additional 5-HTT ko mice once a day for 2 consecutive days $(0.01 \mathrm{ml} / \mathrm{g}$ of a $30 \mathrm{mg} / \mathrm{ml}$ solution) between $\mathrm{P} 0$ and $\mathrm{P} 5$, and pups were killed at P7. Control animals received equal amounts of saline solution.

VMAT2 ko mice typically die within the first $72 \mathrm{hr}$ after birth (Takahashi et al., 1997; Wang et al., 1997). However, 6 of the 77 pups grown to P7 for this study revealed VMAT2 ko status and were assessed together with $43 \mathrm{hz}$ and $28 \mathrm{wt}$ animals (see Table 1). VMAT ko pups displayed great variability in body growth rates, ranging from no postnatal increase in body weights to growth rates largely comparable to those of wt and hz pups from the same litters (see Results).

Neonatal and adult mice were anesthetized using hypothermia and chloral hydrate, respectively, and were perfused with PBS followed by 4\% paraformaldehyde.

Histology and immunohistochemistry. Whole brains or cortices flattened between $1 \mathrm{~mm}$ spacers were post-fixed overnight in $4 \%$ paraformaldehyde, cryoprotected in $30 \%$ sucrose for $24 \mathrm{hr}$, frozen, and cut into $50-\mu \mathrm{m}$-thick cryostat sections. Free-floating tangential sections of flattened cerebral cortex were stained for CO (Wong-Riley and Welt, 

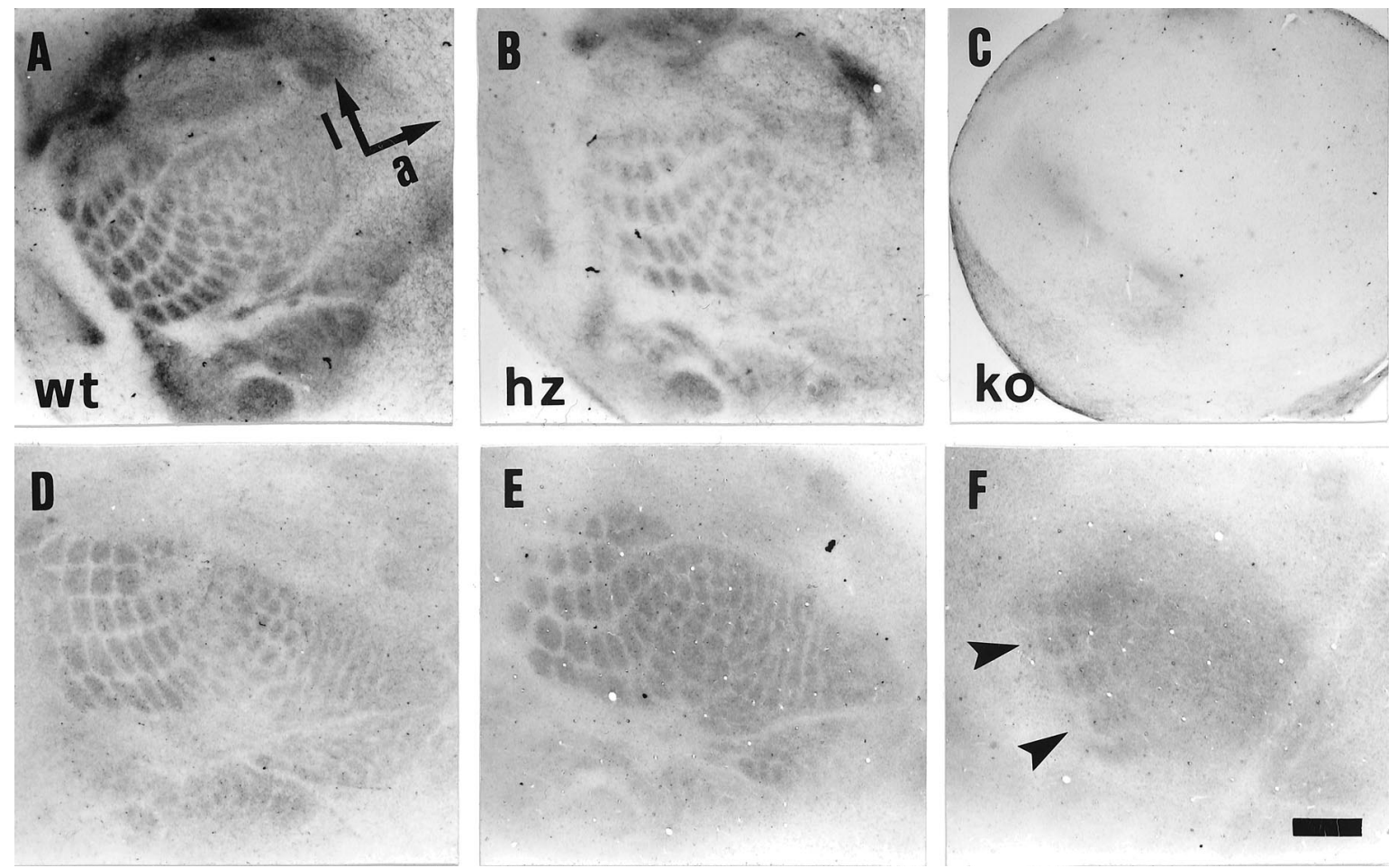

Figure 2. Barrel pattern in tangential sections through the primary somatosensory cortex of 5-HTT wt $(A, D)$, hz $(B, E)$, and ko $(C, F)$ mice. $A-C, 5$-HT immunocytochemistry of P7 brains; $D-F$, CO staining of adult brains. In 5-HTT ko mice $(F)$, the barrel pattern is lost, except for the more caudal PMBSF barrels (arrowheads). The anterior-posterior (a) and mediolateral $(l)$ axes are indicated in $A$. Scale bar (shown in $F$ ): $A, B, D-F, 740 \mu \mathrm{m} ; C$, $1380 \mu \mathrm{m}$.

1980). Consecutive coronal sections were either (1) mounted onto gelatin-coated slides and Nissl stained using toluidine blue, (2) stained free-floating for CO (Wong-Riley and Welt, 1980) or acetylcholinesterase (AChE) (Hedreen et al., 1985), as described (Persico et al., 1997), or (3) immunohistochemically stained for 5-HT, 5-HTT, or VMAT2, as follows: free-floating sections were rinsed in PBS, incubated for 30-60 min in 2\% BSA dissolved in PBS with $0.04 \%$ (5-HTT) or $0.2 \%$ (5-HT and VMAT2) Triton X-100, incubated overnight at room temperature in PBS with $0.04 \%$ Triton X-100 (PBST) containing primary antibodies directed against 5-HT (Incstar, Stillwater, MN; 1:90,000 dilution), 5-HTT (Incstar; 1:5,000 dilution), or VMAT2 (1: 500 dilution) (Takahashi et al., 1997). Sections were then rinsed three times in PBST, incubated for 90 min in PBST containing biotinylated goat anti-rabbit IgG for 5-HT and VMAT2, or HRP-conjugated donkey anti-goat IgG for 5-HTT (Chemicon, Temecula, CA; 1:500 dilution), and washed three times in PBST. 5-HTT immunolabeling was then revealed directly in PBS with $0.05 \%$ DAB and $0.0075 \% \mathrm{H}_{2} \mathrm{O}_{2}$. Instead, 5-HT- and VMAT2-labeled sections were processed by the avidin-biotin-peroxidase method, using the Vectastain ABC immunoperoxidase kit (Vector Laboratories, Burlingame, CA), washed three times in PBST, and developed in $50 \mathrm{~mm}$ Tris, $\mathrm{pH}$ 7.6, with $0.05 \%$ 3,3'-diaminobenzidine tetrahydrochloride (DAB; Sigma, St. Louis, MO), $0.1 \%$ nickel ammonium sulfate, and $0.0075 \% \mathrm{H}_{2} \mathrm{O}_{2}$. Sections selected for GAT-1 staining were preincubated for $2 \mathrm{hr}$ in PB containing $0.25 \%$ Triton $\mathrm{X}-100$ and $3 \%$ normal goat serum. Thereafter, the sections were incubated for $24 \mathrm{hr}$ at $4^{\circ} \mathrm{C}$ in the latter solution, to which was added 1:500 rabbit anti-GAT-1 (Chemicon). The sections were further processed as described above. Control sections for immunocytochemistry included replacement of the primary antibody with normal serum or using an inappropriate secondary antibody. No significant staining was observed under these control conditions.

The same solutions were used for immunocytochemistry at the electron microscopic level, omitting the Triton X-100. After several rinses with $\mathrm{PB}$, the sections were processed by the avidin-biotin-peroxidase method. Thereafter, sections were prepared for electron microscopy (EM) as described below or mounted onto glass slides, dehydrated, cleared with xylene, and coverslipped.

Measurements of whisker barrel areas and posteromedial barrel subfield size in VMAT2 animals. CO-stained tangential sections were used to measure single-barrel cross-sectional areas and total posteromedial subfield (PMBSF) surface in VMAT2 animals using the Kontron Imaging System KS100 (Kontron Elektronik, Eching bei, Munchen, Germany), as described (Persico et al., 2000).

Tissue preparation for electron microscopy: quantitative electron microscopic analysis. A total of eight postnatal day 8 (P8) mice (four wt and four ko animals) were used. The mice were anesthetized by chilling on ice and then perfused through the heart with PBS and then with $4 \%$ paraformaldehyde in $0.1 \mathrm{M}$ PB. The brains were removed, post-fixed overnight, and soaked in a cryoprotective solution (20\% glycerol, $2 \%$ DMSO in distilled water). They were then cut serially at $50 \mu \mathrm{m}$ on a vibratome in the coronal plane, and the tissue sections were processed either to reveal CO activity or for 5-HT or GAT-1 immunocytochemistry, as described above. Adjacent unstained sections were used for conventional EM (see below).

The optic-electron microscopy correlation method (DeFelipe and Fairén, 1993) was used to identify layer IV synapses. Briefly, sections were osmicated in $1 \%$ osmium tetroxide, dehydrated, and flat-embedded in Araldite resin. The plastic-embedded sections were then serially resectioned into semithin ( $2 \mu \mathrm{m}$ thick) sections using a Reichert ultramicrotome. Semithin sections were stained with $1 \%$ toluidine blue in $1 \%$ borax, examined with the light microscope to identify cortical layers, and photographed. Selected semithin sections were resectioned into serial ultrathin sections with a silver-gray interference color. The main advantage of this method is that it allows an accurate study of light microscopic-selected neuropil regions within layer IV (DeFelipe and Fairén, 1993). The ultrathin sections were collected on Formvar-coated single-slot grids, stained with uranyl acetate and lead citrate, and examined in a Jeol-1200 EX electron microscope.

Synaptic density per unit area was estimated from 10 electron microscopic samples of neuropil from layer IV per animal (DeFelipe et al., 1999). In wt animals, we sampled neuropil only from the centers or hollows of the barrels, the region of termination of thalamic afferents (White, 1979), whereas in ko mice the neuropil was sampled from regions within layer IV that showed lower cellular density. These samples were nonoverlapping electron micrographs taken at an initial magnification of $10,000 \times$ and printed at a final magnification of $30,000 \times$. All synapses were counted in 

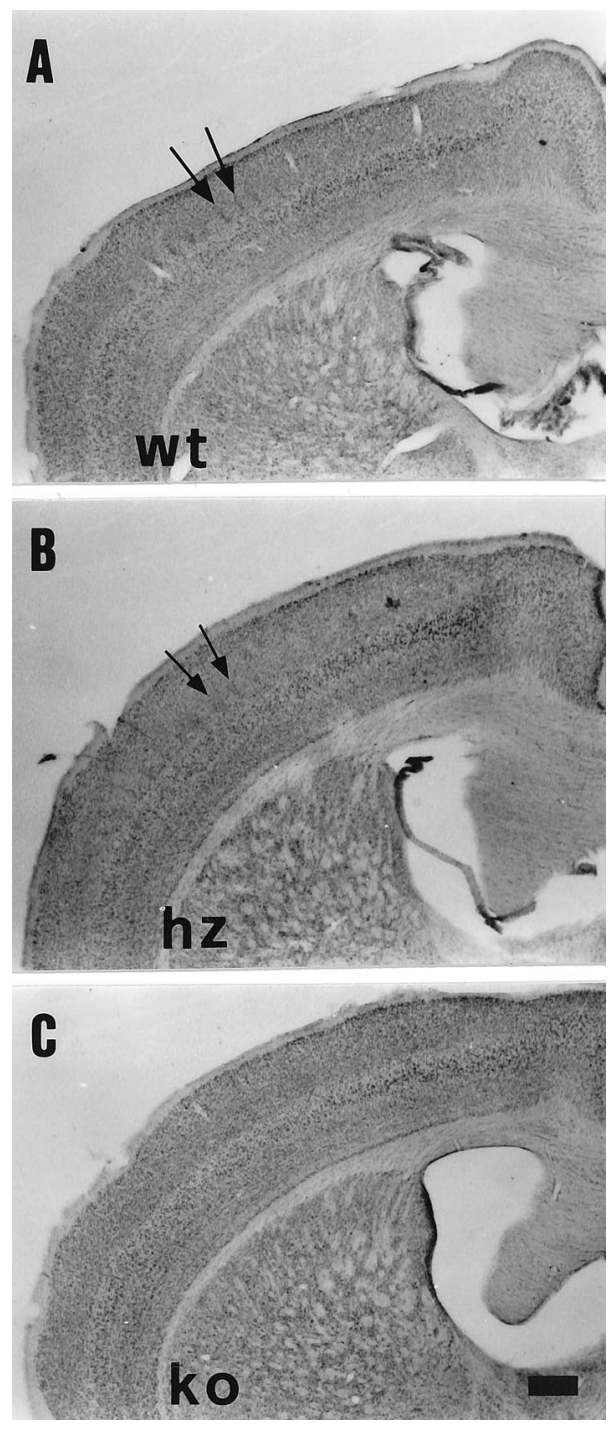

Figure 3. Nissl staining of coronal sections through the somatosensory cortex in adult 5-HTT wt $(A)$, hz $(B)$, and ko $(C)$ mice. Arrows in $A$ and $B$ point toward two adjacent barrel septa. Notice that the septa appear to be enlarged in $B$ and are absent in $C$. Scale bar (shown in $C$ ): $A-C, 400 \mu \mathrm{m}$.

each print within an unbiased counting frame (Gundersen, 1977), which represented $35 \mu \mathrm{m}^{2}$ of tissue. Synaptic profiles touching the exclusion lines were not counted. Synapses were identified after well established morphological criteria (Peters and Palay, 1996), regardless of the angle of section at which the synaptic junctions were viewed. The numerical density of synapses per unit volume of neuropil was calculated using the formula $N_{\mathrm{V}}=$ $N_{\mathrm{A}} / d$ with $N_{\mathrm{A}}$ being the number of synapses per unit area and $d$ the average length of synaptic contacts (DeFelipe et al., 1999). The lengths of synaptic contacts (synaptic apposition length) of all synapses were measured in the prints using a magnetic tablet (SummaSketch III) and the NIH Image analysis program.

Statistical analyses. Data are presented as mean \pm SEM. Means are compared using one-way ANOVA, followed by a priori contrasts or Student-Newman-Keuls post hoc tests. Nonparametric ANOVA (i.e., the Kruskal-Wallis test) has been applied only to VMAT body weights, which were neither normally distributed nor homogeneous in variance, despite data transformation.

\section{RESULTS}

\section{Permanent, PCPA-reversible alterations in the barrel} cortex of 5-HTT ko mice

Brains from 5-HTT wt, hz, and ko mice display no difference in VMAT2 immunoreactivity and amounts of 5-HTT immunoreac- tivity as expected on the basis of genotypic status (data not shown). In contrast, 5-HTT ko mice lack the transient barrel-like 5-HT pattern clearly visible at $\mathrm{P} 7$ in wt and hz animals (Figs. 1, $A$ and $D$ vs $B$ and $E$ vs $C$ and $F ; 2 A-C)$ and show only sparse serotonin-immunolabeled fibers (Fig. $1 F$ ).

Layer IV of the somatosensory cortex shows diff use CO staining both in neonatal and in adult 5-HTT ko brains, instead of the CO-stained patches typically visible in wt and hz animals (Figs. 1, $G$ and $J$ vs $H$ and $K$ vs $I$ and $L, 2 D-F$ ). Only few among the largest, most caudal whisker barrels located in the PMBSF are preserved in tangential sections (Fig. $2 F$, arrowheads). Although cortical layers appear normally developed in adult 5-HTT ko brains, Nissl-stained coronal sections confirm the absence of barrel septa in layer IV (Fig. 3C). Interestingly, 5-HTT hz cortices display an intermediate phenotype, with enlarged barrel septa (Fig. 3B). Thalamic barreloids are present in adult 5-HTT ko mice (Fig. 4A-C); however, ventromedial barreloids, projecting to the anterolateral cortical barrel fields, are less defined in hz and blurred in ko animals, compared with wt mice (Fig. 4B, C, arrowheads). Trigeminal barrelettes appear normal in wt and hz animals (Fig. 4D,E), and less organized in 5-HTT ko mice (Fig. 4F).

These barrel pattern alterations do not stem from malnourishment or altered growth rates, because body and brain weights do not differ significantly by genotype at either age (Table 1). Instead, inhibition of 5-HT synthesis by systemic PCPA $(300 \mathrm{mg} / \mathrm{kg}$, s.c.) effectively restores normal barrel patterns in 5-HTT ko animals, if the first PCPA injection is performed within $36 \mathrm{hr}$ after birth (Fig. 5). PCPA administered at later times rescues the barrel pattern to a progressively lesser extent, and ko animals injected at P4 and P5 display patterns identical to those of untreated or saline-treated ko pups (Fig. 5C, compare with Fig. $2 F$ ).

In contrast, immunoreactivity against the GABA transporter GAT-1 does not reveal substantial differences between 5-HTT ko and wt animals. In both groups of animals, all cortical layers display similar GAT-1 immunoreactivity (Fig. 6A-D). EM immunocytochemistry shows GAT-1 immunoreactive terminals forming symmetrical contacts with postsynaptic elements (Fig. 7B), confirming previous findings (Minelli et al., 1995).

On the other hand, abundant 5-HT immunoreactive terminal boutons are found in layer IV of wt mice only. A number of these terminal boutons are large, are filled with synaptic vesicles, and contain several small mitochondrial profiles; many of them establish prominent asymmetrical synaptic junctions (Fig. 7A). Such morphological characteristics are typical of thalamocortical axonal boutons (Freund et al., 1989). In contrast, no 5-HT immunopositive terminal boutons of this kind could be found in 5-HTT ko mice. Only sparse, small 5-HT immunoreactive axon terminals were detected, but none of several dozen examined in single ultrathin sections (data not shown) was found to form synaptic contacts.

\section{Quantitative analyses of synapses in layer IV of 5-HTT ko versus wt animals at P8}

The optic-electron microscopic method used to quantify synapses in layer IV is illustrated in Figure 8. Selected $2 \mu \mathrm{m}$ semithin sections from 5-HTT wt and ko animals were resectioned for conventional EM to estimate the numerical density of synapses per volume and the length of the synaptic contacts in layer IV. Synapses were classified into three kinds: asymmetrical, symmetrical, and uncharacterized. The former two were identified mainly by the thickness of their postsynaptic densities (Peters and Palay, 1996), whereas uncharacterized synapses were those that could not be clearly identified as either asymmetrical or symmet- 

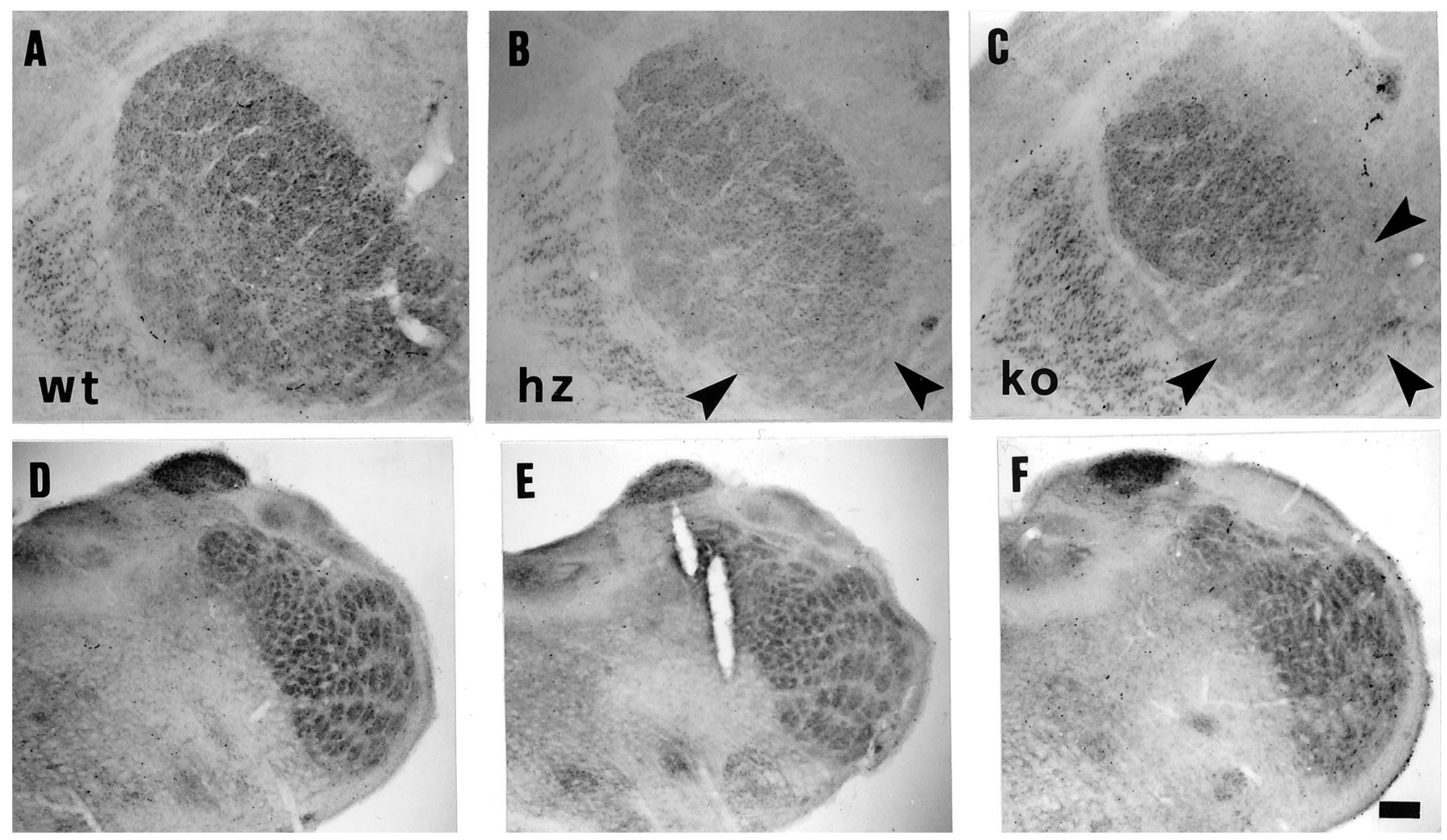

Figure 4. Thalamic barreloids and trigeminal barrelettes in adult 5-HTT wt $(A, D)$, hz $(B, E)$, and ko $(C, F)$ mice, revealed by $\mathrm{CO}$ staining. $A-C$, Thalamic ventrobasal complex. Arrowheads in $B$ and $C$ point to the ventromedial portion of the barrelloid pattern, which appears less distinct in 5-HTT hz $(B)$, compared with wt animals $(A)$, and virtually absent in ko animals $(C) . D-F$, Spinal trigeminal nucleus. Trigeminal barrelettes appear normal in wt and hz animals $(D, E)$, and less organized in ko animals $(F)$. Scale bar (shown in $F$ ): $A-C, 100 \mu \mathrm{m} ; D-F, 160 \mu \mathrm{m}$.

rical, because of the plane of section or ill-defined postsynaptic densities (DeFelipe et al., 1999).

As shown in Table 2, the mean synaptic length of asymmetrical, symmetrical, and uncharacterized synapses is virtually identical in wt and ko mice. In addition, there is no significant difference in synaptic density between the two groups of animals for any type of synapse.

\section{Preserved cortical development and barrel pattern formation in VMAT2 ko mice}

The six VMAT2 ko pups assessed in this study greatly differ in postnatal growth rates, ranging from body weights at $\mathrm{P} 7$ that are practically identical to those of wt and hz pups from the same litters to a complete lack of postnatal growth (Table 1), consistent

\begin{tabular}{|c|c|c|c|c|c|}
\hline 5-HTT & $\mathrm{wt}$ & $\mathrm{hz}$ & ko & One-way ANOVA & $p$ value \\
\hline$n$ assessed at $\mathrm{P} 7$ & 12 & 12 & 9 & & \\
\hline Mean body weights (gm) & $4.58 \pm 0.12$ & $4.28 \pm 0.39$ & $3.84 \pm 0.15$ & $F=1.843(\mathrm{df}=2,29)$ & 0.178 , n.s. \\
\hline Mean brain weights (gm) & $0.21 \pm 0.02$ & $0.22 \pm 0.02$ & $0.23 \pm 0.02$ & $F=0.142(\mathrm{df}=2,29)$ & 0.812 , n.s. \\
\hline$n$ assessed at $4-5$ months & 21 & 15 & 19 & & \\
\hline Mean body weights (gm) & $34.60 \pm 1.22$ & $34.13 \pm 1.40$ & $34.87 \pm 1.47$ & $F=0.121(\mathrm{df}=2,52)$ & 0.886 , n.s. \\
\hline Mean brain weights (gm) & $0.35 \pm 0.05$ & $0.35 \pm 0.01$ & $0.33 \pm 0.01$ & $F=1.107(\mathrm{df}=2,52)$ & 0.338 , n.s. \\
\hline VMAT2 & wt & $\mathrm{hz}$ & ko & Kruskal-Wallis test/one-way ANOVA & $p$ value \\
\hline Total $n$ assessed at P7 & 28 & 43 & 6 & & \\
\hline Mean body weights (gm) & $4.86 \pm 0.24$ & $4.84 \pm 0.19$ & $3.70 \pm 0.67$ & $\mathrm{KW} \chi^{2}=1.884(\mathrm{df}=2)$ & 0.390 , n.s. \\
\hline$n$ assessed at $\mathrm{P} 7$ in tangential sections & 22 & 28 & 2 & & \\
\hline Mean body weights (gm) & $4.26 \pm 0.20$ & $4.02 \pm 0.20$ & $1.63 \pm 0.03^{*}$ & $F=6.706(\mathrm{df}=2,51)$ & $<0.01$ \\
\hline Mean brain weights (gm) & $0.14 \pm 0.01$ & $0.13 \pm 0.01$ & $0.08 \pm 0.001^{*}$ & $F=3.362(\mathrm{df}=2,51)$ & $<0.05$ \\
\hline Mean barrel areas $\left(\mu \mathrm{m}^{2}\right)$ & $29162 \pm 2091$ & $30705 \pm 1713$ & $17784 \pm 374^{*}$ & $F=4.401(\mathrm{df}=2,17)$ & $<0.05$ \\
\hline Mean barrel area/brain weight $\left(\mu \mathrm{m}^{2} / \mathrm{mg}\right)$ & $9587.9 \pm 442$ & $9169.0 \pm 602$ & $9216.5 \pm 258$ & $F=0.181(\mathrm{df}=2,15)$ & 0.836 , n.s. \\
\hline Mean barrel septa/area ratios & 1.11 & 1.06 & 1.00 & $F=0.173(\mathrm{df}=2,16)$ & 0.843 , n.s. \\
\hline
\end{tabular}

*Both ko versus wt and ko versus hz, $p<0.01$ by a priori contrasts. n.s., Not significant. 

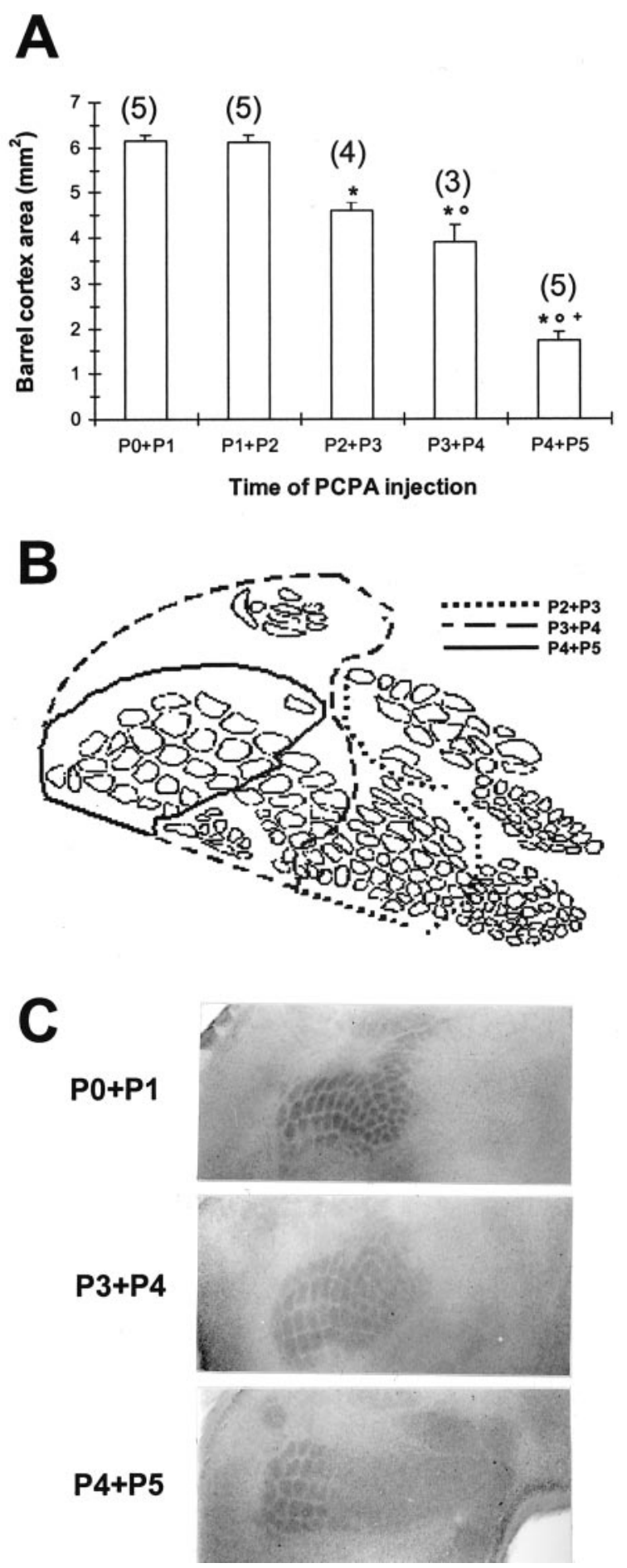

Figure 5. Recovery of somatosensory cortical barrel patterns in 5-HTT ko mice by systemic PCPA $(300 \mathrm{mg} / \mathrm{kg}$ ) injected once daily for 2 consecutive days in early postnatal life. If the injections are performed after P2, only the PMBSF barrels are rescued. The barrel pattern was revealed with $\mathrm{CO}$ staining. $A$, Significant decrease in barrel cortex area when the first PCPA injection is performed later than P1 [one-way ANOVA: $F=96.1$ $(\mathrm{df}=4,21), p<0.001]$. Symbols represent significant differences $(p<$ $0.05)$ from $P 0+P 1$ and $P 1+P 2(*)$, from $P 2+P 3(\circ)$, and from $P 3+P 4(+)$. Sample sizes are shown in parentheses above each column. $B$, Schematic representation of somatosensory cortical barrel fields visible in F2 5-HTT ko mice treated with PCPA on 2 consecutive postnatal days. $C$, Representative examples of different degrees of rescue by PCPA, depending on time of PCPA injection. The time points of PCPA injections are indicated on the left of the photomicrographs.
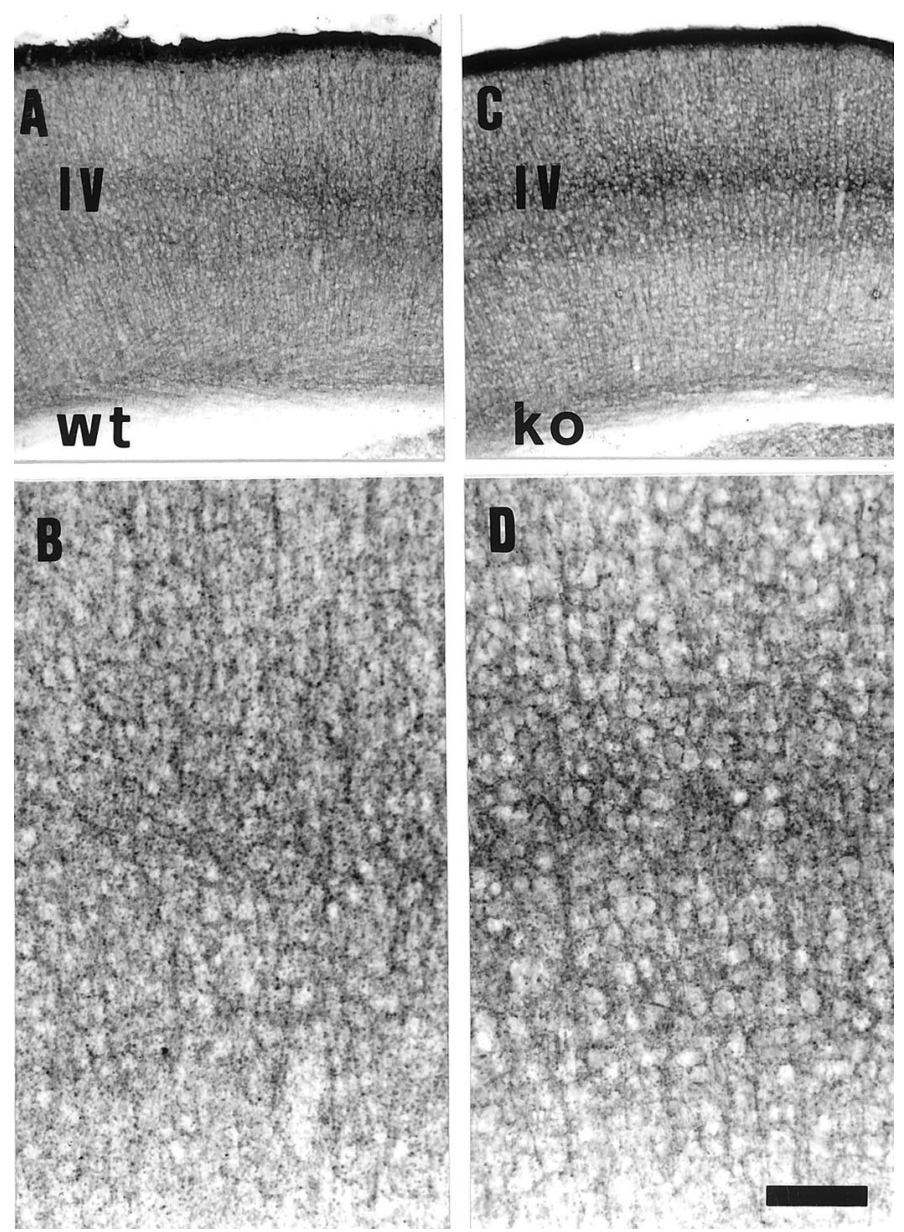

Figure 6. GAT-1 immunostaining of the somatosensory barrel cortex of 5-HTT wt $(A, B)$ and ko $(C, D)$ mice. $A, C$, Low-power magnification of 5-HTT wt $(A)$ and 5-HTT ko $(C)$ mice, showing all cortical layers. Layer IV is indicated $(I V) . B, D$, High-power magnification of layer IV of wt $(B)$ and ko $(D)$ mice. Scale bar (shown in $D$ ): $A, C, 280 \mu \mathrm{m} ; B, D, 110 \mu \mathrm{m}$.

with previous reports (Takahashi et al., 1997; Wang et al., 1997). VMAT2 ko cortices always show a complete lack of 5-HT immunostaining, in contrast to cortices from wt and hz pups (Fig. 9). Comparable amounts of 5-HTT immunoreactivity are instead present in VMAT2 wt, hz, and ko mice, both in the cortex and in serotonin-synthesizing cell bodies in the raphe nuclei (data not shown). Despite undetectable levels of 5-HT in the cortex, and regardless of decreased postnatal growth rates, all VMAT2 ko pups assessed in this study display surprisingly well developed somatosensory cortical barrels, evident at P7 in layer IV with CO staining (Fig. 10F). In fact, the two VMAT2 ko pups assessed in tangential sections (Fig. 10F) were those displaying the lowest postnatal growth (Table 1). Predictably, cross-sectional barrel areas measured in CO-stained tangential sections from these two ko mice are significantly smaller by 39.0 and $42.1 \%$, compared with litter-matched wt and hz mice, respectively (Table 1). These differences disappear, however, after normalizing the PMBSF area by brain weight (Table 1). Furthermore, ko barrel septa are nonsignificantly enlarged by only 11 and $6.5 \%$, compared with wt and hz brains, respectively (Table 1).

\section{DISCUSSION}

Our results demonstrate that (1) removal of extracellular 5-HT by transient 5-HTT expression in thalamocortical terminals of neo- 

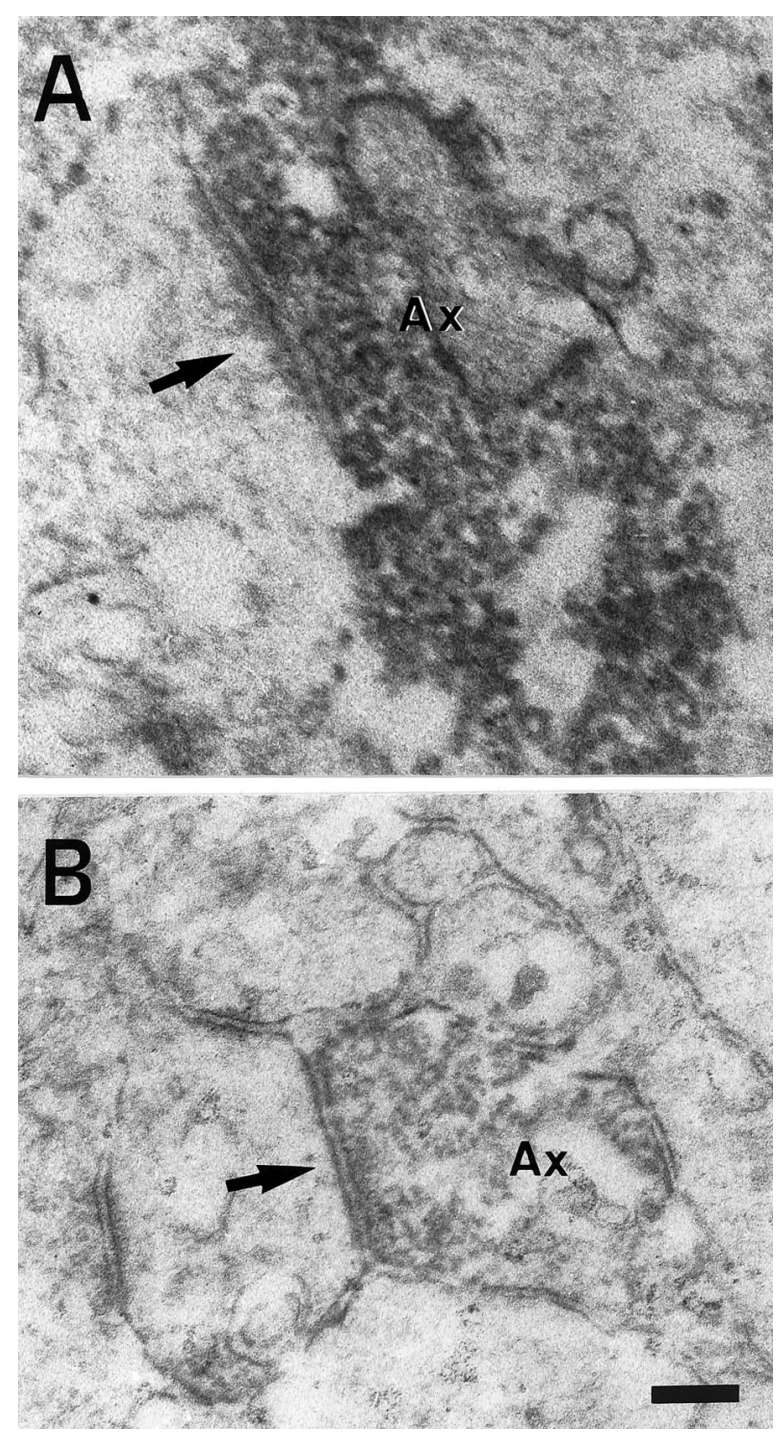

Figure 7. Electron micrographs showing 5-HT $(A)$ and GAT-1 $(B)$ immunostaining in layer IV of the barrel cortex. $A, 5$-HT-immunostained axon terminal $(A x)$, forming an asymmetrical contact (arrow) with a dendritic profile, in a 5-HTT wt mouse. $B$, GAT-1-immunostained axon terminal $(A x)$, forming a symmetrical synaptic contact (arrow) with a dendritic profile, from cortical layer IV of a 5-HTT ko mouse. Scale bar (shown in $B$ ): $A, B, 0.2 \mu \mathrm{m}$.

natal rodents is essential for normal barrel pattern development, (2) excess of extracellular 5-HT does not affect synaptic density in layer IV, (3) the fate of 5-HT after uptake into thalamocortical terminals (i.e., degradation vs vesicular storage and release) does not influence cortical barrel formation, and (4) profound 5-HT depletion and lack of vesicular 5-HT release are unlikely to play relevant roles in barrel formation and barrel size determination.

\section{Possible mechanisms of serotonin-induced alterations in 5-HTT ko and hz barrel cortex}

The permanent alterations in cortical barrel pattern displayed by 5-HTT ko mice clearly demonstrate that excessive amounts of extracellular 5-HT are detrimental to somatosensory cortical development. The rescue of normal barrel development by early postnatal PCPA administration proves in both models the specificity of 5-HT involvement. The cellular targets of 5-HT modulatory action in somatosensory cortical development have not been elucidated conclusively. In principle, 5-HT may act on thalamocortical axon arbors, which play a pivotal role in specifying somatosensory cortical barrel pattern formation (Erzurumlu and Jhaveri, 1990; Jhaveri et al., 1991), and on their target neurons located in layers II-VI, particularly on those with the cell body located in layer IV.

Barrel cortex alterations seen in 5-HTT ko mice are similar to those previously described in MAO-A ko mice (Cases et al., 1996) and more recently in MAO-A/5-HTT double ko mice (Salichon et al., 2001), albeit somewhat less severe. A similar phenotype is also present in barrelless mouse mutants, attributable to inactivation of type 1 adenylate cyclase (Abdel-Majid et al., 1998), and in GAP-43 ko mice (Maier et al., 1999). Furthermore, mice with selective lack of expression of NMDAR1 receptor in the cerebral cortex show an altered barrel pattern (Iwasato et al., 2000). Thalamocortical terminals transiently express $5-\mathrm{HT}_{1 \mathrm{~B}}$ receptors, the stimulation of which inhibits thalamic neuronal firing rates (Bennett-Clarke et al., 1993; Rhoades et al., 1994) and disorganizes thalamic afferents and barrel formation (Young-Davies et al., 2000). Involvement of thalamocortical afferents in barrel pattern alterations characteristic of 5-HTT ko mice also receives support from the overlap between the critical period that we describe in this study for reversal by PCPA and the critical period for vibrissal denervation effects on barrel pattern formation in mice (Woolsey and Wann, 1976). Thus, a coherent picture emerges from this and from previous studies whereby excess extracellular 5-HT could affect growth of thalamocortical axon branches via a $5-\mathrm{HT}_{1 \mathrm{~B}}$ receptor-adenylate cyclase inhibition-dependent mechanism, possibly involving also GAP-43 as a downstream effector. Recent evidence of 5-HT $\mathrm{HB}_{1 \mathrm{~B}}$ knock-outmediated rescue of sensory map alterations in visual and somatosensory systems of MAO-A/5-HTT double ko mice lends further support to this model (Salichon et al., 2001). In addition, stimulation of presynaptic 5-HT $1 \mathrm{~B}$ receptors could impair differentiation of glutamate-sensitive layer IV granule cells by decreasing glutamate release from thalamocortical terminals.

Recent cell culture studies of thalamic neurons have reported 5-HT stimulatory effects on neurite elongation (Lieske et al., 1999; Lotto et al., 1999). The relatively modest effect size seen in these studies may stem from the cell culture methodology used. In preliminary experiments using a slightly different approach, we find a bell-shaped dose-response curve of cultured embryonic ventroposterior thalamic neurons to 5-HT. Concentrations of up to $30 \mu \mathrm{M} 5$-HT in the culture medium yield $90 \%$ increases in total neurite length and $180 \%$ increases in total branch number, whereas higher 5-HT concentrations lead to inhibition of neurite growth and branching (A. M. Persico, P. Levitt, and F. Keller, unpublished observation). This inhibitory effect might parallel processes occurring in vivo and explain the altered barrel patterns in 5-HTT ko mice.

As mentioned above, the prominent neurodevelopmental alterations seen in 5-HTT ko mice could also stem from cortical targets of 5-HT action. Indeed, serotonin-induced suppression of gap junction couplings between somatosensory cortical cells of neonatal rats strongly supports a role for 5-HT in the establishment of cell-to-cell contacts within the cortex (Rorig and Sutor, 1996). Interestingly, the dendrites of pyramidal cells express 5-HT $\mathrm{HA}_{2 \mathrm{~A}}$ receptors (Cornea-Hebert et al., 1999), the receptor subtype most frequently involved in cell migration in non-neural tissues (see below). Should cortical granule cells prove to be as sensitive to 5-HT as thalamic neurons, enhanced dendritic growth 

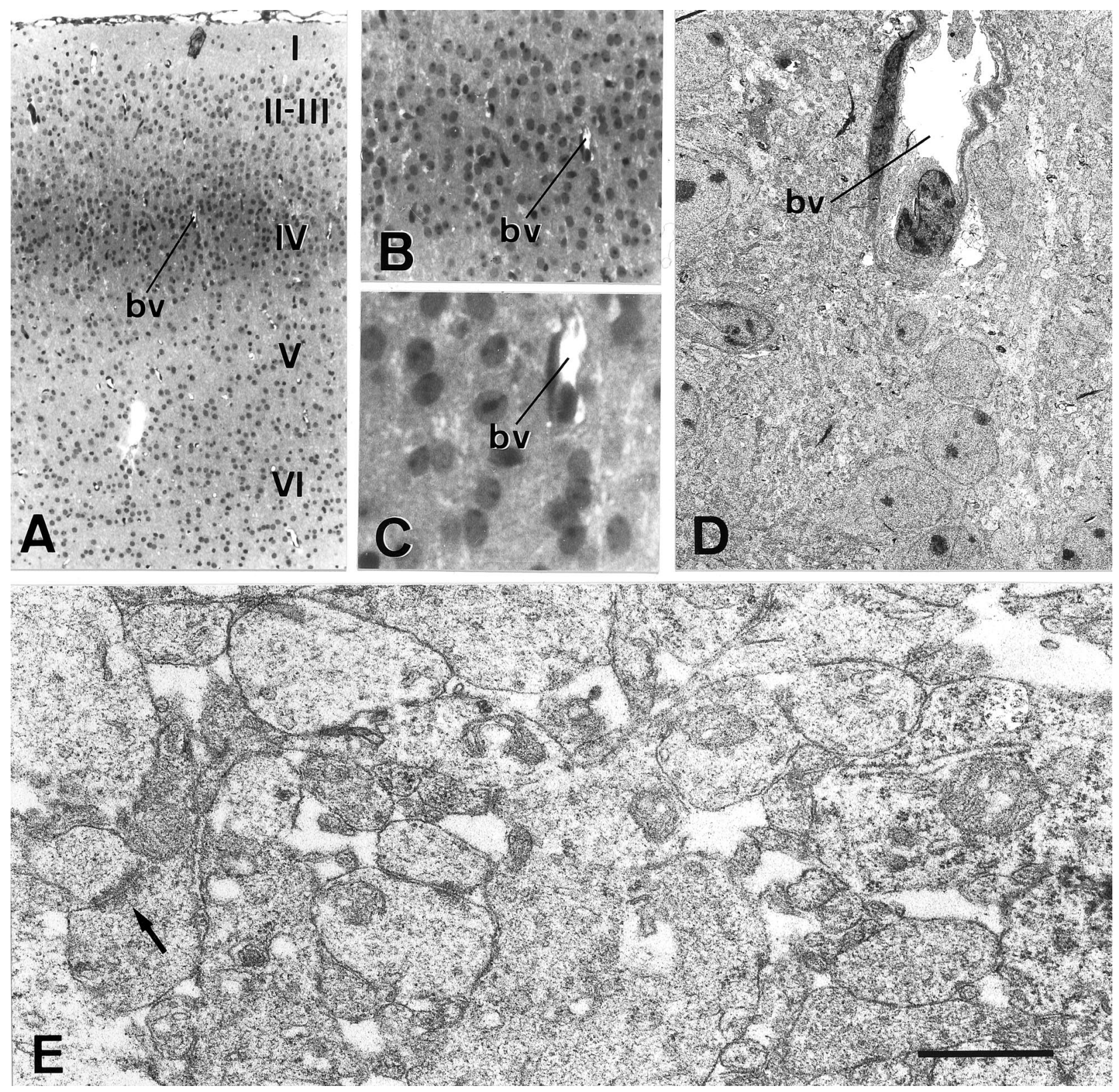

Figure 8. Optic-electron microscopy correlation method used in this study. $A$, Semithin section through the somatosensory cortex of a P8 mouse, counterstained with toluidine blue; layer IV is always clearly visible because of its higher cell density. $b v$, Blood vessel. $B, C$, Same as in $A$, at a higher magnification. $D$, Ultrathin section of the same area as in $C$, obtained after resectioning the area of interest. $E$, Example of a neuropil-rich area within layer IV, photographed to carry out the quantitative study. The arrow points to a synaptic contact. Scale bar (shown in $E$ ): $A ; 200 \mu \mathrm{m} ; B, 100 \mu \mathrm{m} ; C$, $30 \mu \mathrm{m} ; D, 7 \mu \mathrm{m} ; E, 520 \mathrm{~nm}$.

toward barrel centers might contribute to moving granule cell bodies toward the septa.

At the cellular level, several previous in vitro and in vivo studies suggest that extracellular 5-HT levels may affect synaptic density or neurite branching and elongation in nonserotoninergic cortical neurons (Chubakov et al., 1986; Haydon et al., 1987; Okado et al., 1989, Sikich et al., 1990; Okado et al., 1993; Chen et al., 1994; Niitsu et al., 1995; Yan et al., 1997). The results of our quantitative electron microscopic study provide no evidence of enhanced extracellular 5-HT exerting either a positive or a negative effect on synapse formation. Previous in vivo studies largely focus on the effects of pharmacologically induced 5-HT depletion, the limitations of which have been discussed previously (Persico et al.,
2000). We do not exclude the possibility that decreased extracellular 5-HT may affect synapse formation or that enhanced or reduced extracellular 5-HT may yield altered microcircuitry, not necessarily resulting in altered synaptic density.

A developmental role of 5-HT has been described previously in non-neural tissues as diverse as the palate and craniofacial mesenchyme (Zimmerman et al., 1983; Shuey et al., 1992; Moiseiwitch and Lauder, 1995), the heart (Yavarone et al., 1993; Choi et al., 1997), and the endothelium and vascular smooth muscle (Bottaro et al., 1985; Bell and Madri, 1989; Tamura et al., 1997). All these tissues show a transient expression of 5-HTT, as well as vesicular accumulation of 5-HT likely mediated by a VMAT. Most importantly, 5-HT concentration-dependent modulation of 


\begin{tabular}{|c|c|c|c|c|}
\hline Type of synapses & Group & $\begin{array}{l}\text { Number of synaptic } \\
\text { particles counted }\end{array}$ & $\begin{array}{l}\text { Mean synaptic } \\
\text { length }(\mu \mathrm{m})\end{array}$ & $\begin{array}{l}\text { Mean synaptic density } \\
\text { by volume }\left(\times 10^{8} / \mathrm{mm}^{3}\right)\end{array}$ \\
\hline \multirow[t]{2}{*}{ Asymmetrical } & wt & 54 & $0.27 \pm 0.01$ & $1.45 \pm 0.19$ \\
\hline & ko & 43 & $0.27 \pm 0.01$ & $1.17 \pm 0.16$ \\
\hline \multirow[t]{2}{*}{ Symmetrical } & wt & 19 & $0.25 \pm 0.02$ & $0.59 \pm 0.12$ \\
\hline & ko & 23 & $0.26 \pm 0.02$ & $0.72 \pm 0.15$ \\
\hline \multirow[t]{2}{*}{ Uncharacterized } & wt & 133 & $0.25 \pm 0.01$ & $3.81 \pm 0.28$ \\
\hline & ko & 153 & $0.26 \pm 0.01$ & $4.47 \pm 0.51$ \\
\hline \multirow[t]{2}{*}{ All types } & wt & 206 & $0.26 \pm 0.01$ & $5.71 \pm 0.30$ \\
\hline & ko & 219 & $0.26 \pm 0.01$ & $6.24 \pm 0.57$ \\
\hline
\end{tabular}

Values are expressed as mean \pm SEM. The total area of neuropil sampled per animal was $350 \mu \mathrm{m}^{2}$ (see Materials and Methods for further details).

cell migration, typically mediated by $5-\mathrm{HT}_{2}$ receptor subtypes, has been reliably documented in all these instances (Zimmerman et al., 1983; Bottaro et al., 1985; Bell and Madri, 1989; Shuey et al., 1992; Yavarone et al., 1993; Moiseiwitch and Lauder, 1995; Choi et al., 1997; Tamura et al., 1997). The involvement of 5-HT in regulating cell migration may be more widespread than anticipated, given the broad distribution of transient 5-HTT immunoreactivity recently described in mouse embryos (Hansson et al., 1999).

\section{Potential relevance of 5-HTT ko phenotypes for human studies}

Recent prospective studies on pregnancy outcome in women treated with selective serotonin reuptake inhibitors (SSRIs) do not support increased teratogenic risks involving major malformations, miscarriage, stillbirth, or prematurity (Kulin et al., 1998; Ericson et al., 1999). Similarly, 5-HTT ko mice assessed in this study do not differ in brain weight, nor do they show overt malformations or display obvious behavioral changes. The neurodevelopmental alterations that we describe at the microscopic level, however, do suggest a potential for changes in neural circuitry and for behavioral teratology in humans. Therefore, prospective follow-up studies of children delivered by mothers treated with SSRIs during pregnancy are warranted.

\section{Implications of normal barrel development in VMAT2 ko mice}

VMAT2 ko pups display remarkably normal cortices. In particular, barrel pattern development in layer IV appears surprisingly well preserved at P7, indicating that vesicular 5-HT release is not essential to barrel pattern formation. In fact, despite extreme 5-HT depletion and no vesicular 5-HT release from raphecortical terminals (Wang et al., 1997), VMAT2 ko pups display only minimal, nonsignificant enlargements of barrel septa (Table 1). Furthermore, when mean barrel area is normalized for brain weight, differences between VMAT2 ko and wt or hz pups disappear (Table 1). This is entirely compatible with an effect of malnutrition, already known to reduce per se cross-sectional barrel areas in neonatal rodents (Vongdokmai, 1980; Persico et al., 2000), that is limited to those VMAT2 ko pups displaying most blunted body growth rates. In this regard, VMAT2 ko mice nicely parallel animals in which 5-HT depletion has been induced by neurotoxins such as parachloroamphetamine and PCPA (Persico et al., 2000).

Reduced or impaired vesicular release of other monoamines,
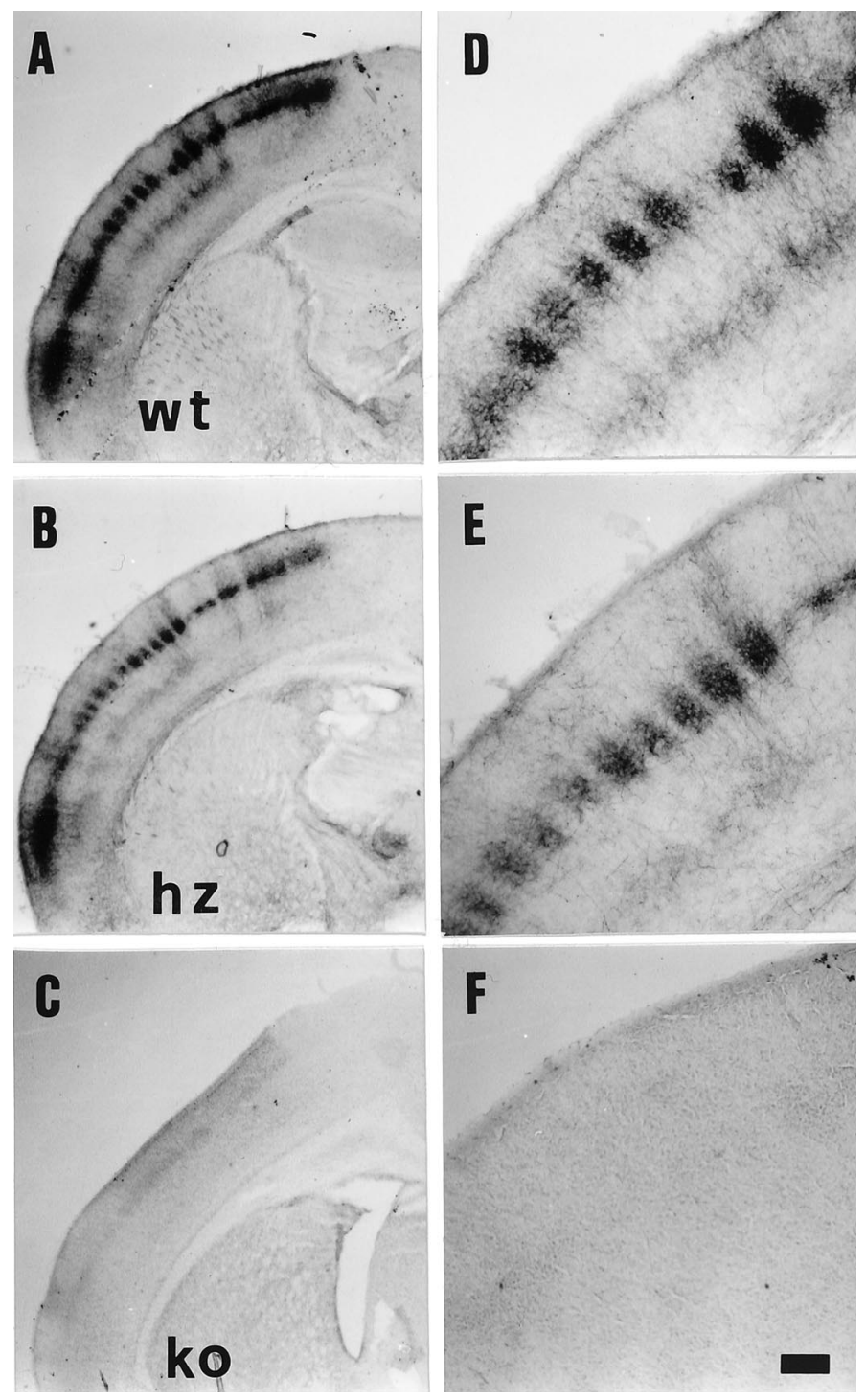

Figure 9. 5-HT immunocytochemistry in brains of VMAT2 wt $(A, D)$, hz $(B, E)$, and ko $(C, F)$ mice assessed at P7. $A-C, 5$-HT immunostaining of coronal sections reveals the barrel pattern in wt and hz mice; no 5-HT immunostaining is visible in VMAT2 ko mice $(C)$. $D-F$, Higher magnification of sections shown in $A-C$. Scale bar (shown in $F$ ): $A, B, 400 \mu \mathrm{m}$; $C, 430 \mu \mathrm{m} ; D-F, 130 \mu \mathrm{m}$. 

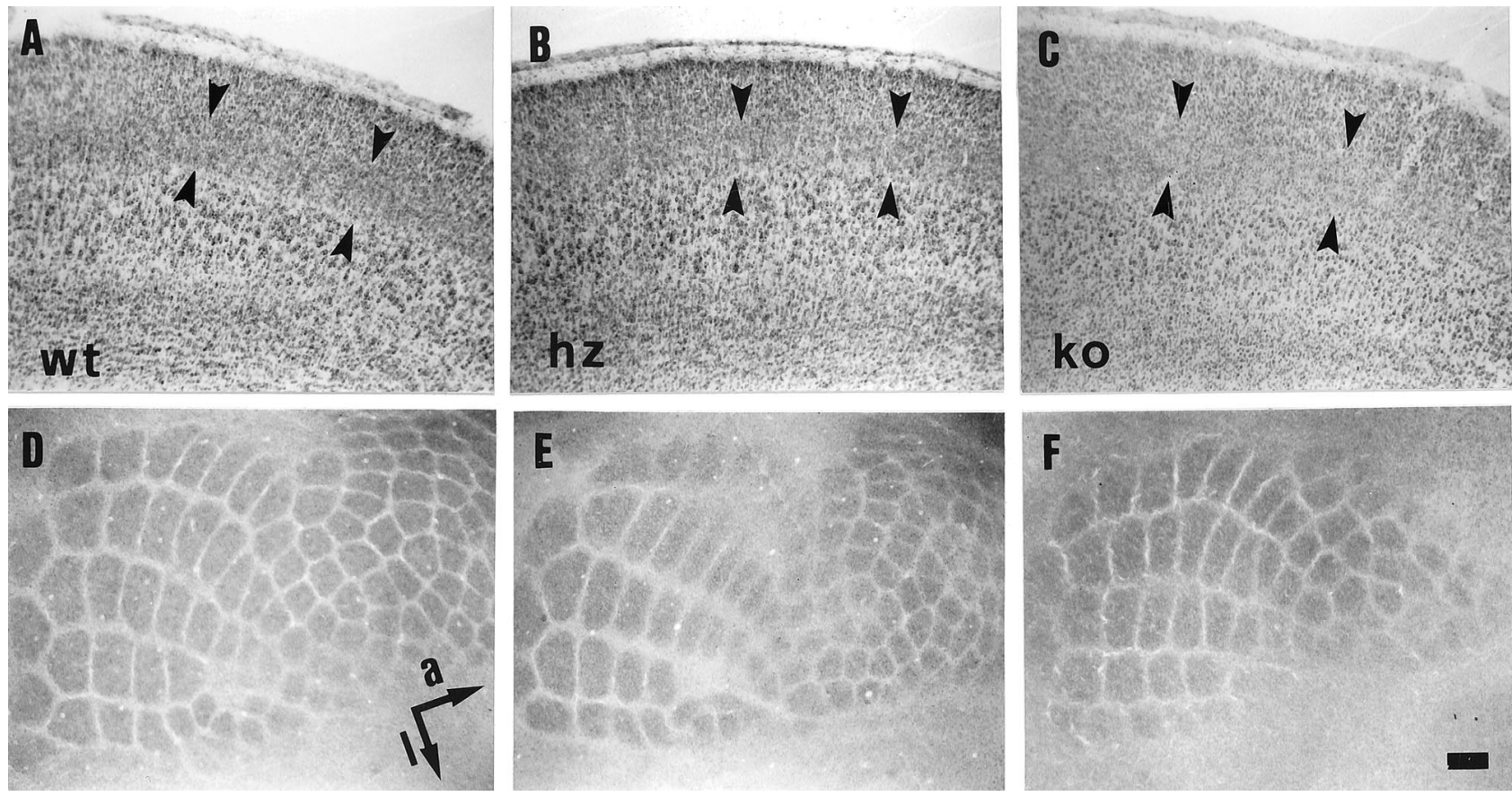

Figure 10. Cortical development and barrel pattern in VMAT2 wt $(A, D)$, hz $(B, E)$, and ko $(C, F)$ mice assessed by Nissl staining and CO histochemistry at P7. A-C, Nissl staining of coronal sections show normal development of all cortical layers. Arrowheads mark the boundaries of layer IV. Barrel septa are less well defined in neonates, compared with adults (Fig. 3). $D-F$, CO staining of tangential sections through layer IV of the PMBSF, displaying normal barrel patterns. The anterior-posterior $(a)$ and medial-lateral $(l)$ axes are indicated in $D$. Scale bar (shown in $F$ ): $A-C, 100 \mu \mathrm{m} ; D$, $E, 180 \mu \mathrm{m} ; F, 140 \mu \mathrm{m}$.

such as norepinephrine (NE), unlikely counteracts potential negative effects of reduced 5-HT release on barrel areas. The reduction or lack of NE release, for example, has been shown to interfere with adult barrel cortex plasticity (Levin and DunnMeynell, 1991) but not with neonatal barrel size (Loeb et al., 1987). Furthermore, we find no alterations in the primary somatosensory cortex of tyrosine hydroxylase knock-out mice (A. M. Persico, A. Portbury, D. Chikaraishi, and F. Keller, unpublished observation). Finally, neurotransmitter release from vesicles is known to be activity dependent. Nonvesicular activityindependent 5 -HT release mediated by reverse transport at the plasma membrane appears unlikely here, because it typically requires high cytosolic agonist concentrations in presynaptic terminals (Sultzer et al., 1995) or a major disruption of ion gradients (Szatkowski et al., 1990). We can rule out the former mechanism, because VMAT2 ko mice are practically devoid of cortical 5-HT immunostaining (Fig. 9). As for the latter possibility, to our knowledge no evidence produced to date supports the existence of altered ion gradients in VMAT2 ko mice.

Therefore, in conjunction with recent evidence underscoring the role played by body growth impairment and possibly by direct damage of thalamocortical terminals produced by serotonindepleting drugs (Persico et al., 2000), our data suggest that extracellular 5-HT deficiency has a very minor impact, if any, on barrel pattern formation, in contrast with the profound derangements produced by extracellular 5-HT excess.

\section{REFERENCES}

Abdel-Majid RM, Leong WL, Schalkwyk LC, Smallman DS, Wong ST, Storm DR, Fine A, Dobson MJ, Guernsey DL, Neumann PE (1998) Loss of adenylyl cyclase I activity disrupts patterning of mouse somatosensory cortex. Nat Genet 19:289-291.

Bailey CH, Chen MC, Keller F, Kandel ER (1992) Serotonin-mediated endocytosis of apCAM: an early step of learning-related synaptic growth in Aplysia. Science 256:645-649.

Bell L, Madri JA (1989) Effect of platelet factors on migration of cultured bovine aortic endothelial and smooth muscle cells. Circ Res 65:1057-1065.

Bengel D, Murphy DL, Andrews AM, Wichems CH, Feltner D, Heils A, Moessner R, Westphal H, Lesch KP (1998) Altered brain serotonin homeostasis and locomotor insensitivity to 3,4-methylenedioxymethamphetamine ("Ecstasy") in serotonin transporter-deficient mice. Mol Pharmacol 53:649-655.

Bennett-Clarke CA, Chiaia NL, Crissman RS, Rhoades RW (1991) The source of the transient serotoninergic input to the developing visual and somatosensory cortices in rat. Neuroscience 43:163-183.

Bennett-Clarke CA, Leslie MJ, Chiaia NL, Rhoades RW (1993) Serotonin $1 \mathrm{~B}$ receptors in the developing somatosensory and visual cortices are located on thalamocortical axons. Proc Natl Acad Sci USA 90:153-157.

Bennett-Clarke CA, Hankin MH, Leslie MJ, Chiaia NL, Rhoades RW (1994a) Patterning of the neocortical projections from the raphe nuclei in perinatal rats: investigation of potential organizational mechanisms. J Comp Neurol 348:277-290.

Bennett-Clarke CA, Leslie MJ, Lane RD, Rhoades RW (1994b) Effect of serotonin depletion on vibrissa-related patterns of thalamic afferents in the rat's somatosensory cortex. J Neurosci 14:7594-7607.

Blue ME, Erzurumlu RS, Jhaveri S (1991) A comparison of pattern formation by thalamocortical and serotoninergic afferents in the rat barrel field cortex. Cereb Cortex 1:380-389.

Bottaro D, Shepro D, Peterson S, Hechtman HB (1985) Serotonin, histamine, and norepinephrine mediation of endothelial and vascular smooth muscle cell movement. Am J Physiol 248:C252-C257.

Cases O, Vitalis T, Seif I, De Maeyer E, Sotelo C, Gaspar P (1996) Lack of barrels in the somatosensory cortex of monoamine oxidase A-deficient mice: role of a serotonin excess during the critical period. Neuron 16:297-307.

Chen L, Hamaguchi K, Ogawa M, Hamada S, Okado N (1994) PCPA reduces both monoaminergic afferents and nonmonoaminergic synapses in the cerebral cortex. Neurosci Res 19:111-115.

Choi DS, Ward SJ, Messaddeq N, Launay JM, Maroteaux L (1997) 5-HT2B receptor-mediated serotonin morphogenetic functions in mouse cranial neural crest and myocardial cells. Development 124:1745-1755.

Chubakov AR, Gromova EA, Konovalov GV, Sarkisova EF, Chumasov 
EI (1986) The effects of serotonin on the morpho-functional development of rat cerebral neocortex in tissue culture. Brain Res 369:285-297.

Chugani DC, Muzik O, Behen M, Rothermel R, Janisse JJ, Lee J, Chugani HT (1999) Developmental changes in brain serotonin synthesis capacity in autistic and nonautistic children. Ann Neurol 45:287-295.

Cornea-Hebert V, Riad M, Wu C, Singh SK, Descarries L (1999) Cellular and subcellular distribution of the serotonin 5-HT2A receptor in the central nervous system of adult rat. J Comp Neurol 409:187-209.

D'Amato RJ, Blue ME, Largent BL, Lynch DR, Ledbetter DJ, Molliver ME, Snyder SH (1987) Ontogeny of the serotoninergic projection to rat neocortex: transient expression of a dense innervation to primary sensory areas. Proc Natl Acad Sci USA 84:4322-4326.

DeFelipe J, Fairén A (1993) A simple and reliable method for correlative light and electron microscopic studies. J Histochem Cytochem 41:769-772.

DeFelipe J, Marco P, Busturia I, Merchán-Pérez A (1999) Estimation of the number of synapses in the cerebral cortex: methodological considerations. Cereb Cortex 9:722-732.

Dori I, Dinopoulos A, Blue ME, Parnavelas JG (1996) Regional differences in the ontogeny of the serotoninergic projection to the cerebral cortex. Exp Neurol 138:1-14.

Ericson A, Kallen B, Wilholm B (1999) Delivery outcome after the use of antidepressants in early pregnancy. Eur J Clin Pharmacol 55:503-508.

Erzurumlu RS, Jhaveri S (1990) Thalamic axons confer a blueprint of the sensory periphery onto the developing rat somatosensory cortex. Dev Brain Res 56:229-234.

Freund TF, Martin KAC, Soltész I, Somogyi P, Whitteridge D (1989) Arborisation pattern and postsynaptic targets of physiologically identified thalamocortical afferents in striate cortex of the macaque monkey. J Comp Neurol 289:315-336.

Fuchs JL (1995) Neurotransmitter receptors in developing barrel cortex. In: Cereb cortex, Vol. 11, The barrel cortex of rodents (Jones EG, Diamond IT, eds), pp 375-409. New York: Plenum.

Fujimiya M, Kimura H, Maeda T (1986) Postnatal development of serotonin nerve fibers in the somatosensory cortex of mice studied by immunohistochemistry. J Comp Neurol 246:191-201.

Glanzman DL, Kandel ER, Schacher S (1990) Target-dependent structural changes accompanying long-term synaptic facilitation in Aplysia neurons. Science 249:799-802.

Goldman-Rakic PS, Brown RM (1982) Postnatal development of monoamine content and synthesis in the cerebral cortex of rhesus monkeys. Dev Brain Res 4:339-349.

Gundersen HJG (1977) Notes on the estimation of the numerical density of arbitrary profiles: the edge effect. J Microsc 111:219-223.

Hansson SR, Mezey E, Hoffman BJ (1999) Serotonin transporter messenger RNA expression in neural crest-derived structures and sensory pathways of the developing rat embryo. Neuroscience 89:243-265.

Haydon PG, McCobb DP, Kater SB (1987) The regulation of neurite outgrowth, growth cone motility, and electrical synaptogenesis by serotonin. J Neurobiol 18:197-215.

Hedreen JC, Bacon SJ, Price DL (1985) A modified histochemical technique to visualize acetylcholinesterase-containing axons. J Histochem Cytochem 33:134-140.

Iwasato T, Datwani A, Wolf AM, Nishiyama H, Taguchi Y, Tonegawa S, Knöpfel T, Erzurumlu R, Itohara S (2000) Cortex-restricted disruption of NMDAR1 impairs neuronal patterns in the barrel cortex. Nature 406:726-731.

Jhaveri S, Erzurumlu RS, Crossin K (1991) Barrel construction in rodent neocortex: role of thalamic afferents versus extracellular matrix molecules. Proc Natl Acad Sci USA 88:4489-4493.

Killackey HP, Rhoades RW, Bennett-Clarke CA (1995) The formation of a cortical somatotopic map. Trends Neurosci 18:402-407.

Koe BK, Weissman A (1966) p-Chlorophenylalanine: a specific depletor of brain serotonin. J Pharmacol Exp Ther 154:499-516.

Kulin NA, Pastuszak A, Sage SR, Schick-Boschetto B, Spivey G, Feldkamp M, Ormond K, Matsui D, Stein-Schechman AK, Cook L, Brochu J, Rieder M, Koren G (1998) Pregnancy outcome following maternal use of the new selective serotonin reuptake inhibitors: a prospective controlled multicenter study. JAMA 279:609-610.

Lebrand C, Cases O, Adelbrecht C, Doye A, Alvarez C, El Mestikawy S, Seif I, Gaspar P (1996) Transient uptake and storage of serotonin in developing thalamic neurons. Neuron 17:823-835.

Leslie MJ, Bennett-Clarke CA, Rhoades RW (1992) Serotonin 1B receptors form a transient vibrissa-related pattern in the primary somatosensory cortex of the developing rat. Dev Brain Res 69:143-148.

Levin BE, Dunn-Meynell A (1991) Adult rat barrel cortex plasticity occurs at 1 week but not at $1 \mathrm{~d}$ after vibrissectomy as demonstrated by 2-deoxyglucose method. Exp Neurol 113:237-248.

Levitt P, Harvey JA, Friedman E, Simansky K, Murphy EH (1997) New evidence for neurotransmitter influences on brain development. Trends Neurosci 20:269-274.
Lieske V, Bennett-Clarke CA, Rhoades RW (1999) Effects of serotonin on neurite outgrowth from thalamic neurons in vitro. Neuroscience 90:967-974.

Loeb EP, Chang FF, Greenough WT (1987) Effects of neonatal 6-hydroxydopamine treatment upon morphological organization of the posteromedial barrel subfield in mouse somatosensory cortex. Brain Res 403:113-120.

Lotto B, Upton L, Price DJ, Gaspar P (1999) Serotonin receptor activation enhances neurite outgrowth of thalamic neurones in rodents. Neurosci Lett 269:87-90.

Maier DL, Mani S, Donovan SL, Soppet D, Tessarollo L, McCasland JS, Meiri KF (1999) Disrupted cortical map and absence of cortical barrels in growth-associated protein (GAP)-43 knockout mice. Proc Natl Acad Sci USA 96:9397-9402.

Mansour-Robaey S, Mechawar N, Radja F, Beaulieu C, Descarries L (1998) Quantified distribution of serotonin transporter and receptors during the postnatal development of the rat barrel field cortex. Dev Brain Res 107:159-163.

Mathews TA, Fedele DE, Unger EL, Lesch KP, Murphy DL, Andrews AM (2000) Effects of serotonin transporter inactivation on extracellular 5-HT levels, in vivo microdialysis recovery, and MDMA-induced release of serotonin and dopamine in mouse striatum. Soc Neurosci Abstr 26:1666.

Minelli A, Brecha NC, Karschin C, De Biasi S, Conti F (1995) GAT-1, a high-affinity GABA plasma membrane transporter, is localized to neurons and astroglia in the cerebral cortex. J Neurosci $15: 7734-7746$.

Moiseiwitch JRD, Lauder JM (1995) Serotonin regulates mouse cranial neural crest migration. Proc Natl Acad Sci USA 92:7182-7186.

Niitsu Y, Hamada S, Hamaguchi K, Mikuni M, Okado N (1995) Regulation of synapse density by 5-HT2A receptor agonist and antagonist in the spinal cord of chicken embryo. Neurosci Lett 195:159-162.

Okado N, Shibanoki S, Ishikawa K, Sako H (1989) Developmental changes in serotonin levels in the chick spinal cord and brain. Dev Brain Res 50:217-223.

Okado N, Cheng L, Tanatsugu Y, Hamada S, Hamaguchi K (1993) Synaptic loss following removal of serotoninergic fibers in newly hatched and adult chickens. J Neurobiol 24:687-698.

Osterheld-Haas MC, Van der Loos H, and Hornung JP (1994) Monoaminergic afferents to cortex modulate structural plasticity in the barrel field of the mouse. Dev Brain Res 77:189-202.

Persico AM, Calia E, Keller F (1997) Implants for sustained drug release over the somatosensory cortex of the newborn rat: a comparison of materials and surgical procedures. J Neurosci Methods 76:105-113.

Persico AM, Altamura C, Calia E, Puglisi-Allegra S, Ventura R, Lucchese F, Keller F (2000) Serotonin depletion and barrel cortex development: impact of growth impairment vs 5-HT effects on thalamocortical endings. Cereb Cortex 10:181-191.

Peters A, Palay SL (1996) The morphology of synapses. J Neurocytol 25:687-700.

Rhoades RW, Bennett-Clarke CA, Chiaia NL, White AF, Macdonald GJ, Haring JH, Jacquin MJ (1990) Development and lesion induced reorganization of the cortical representation of the rat's body surface as revealed by immunocytochemistry for serotonin. J Comp Neurol 293:190-207.

Rhoades RW, Bennett-Clarke CA, Shi MY, Mooney RD (1994) Effects of 5-HT on thalamocortical synaptic transmission in the developing rat. J Neurophysiol 72:2438-2450.

Rice FL (1995) Comparative aspects of barrel structure and development. In: Cereb cortex, Vol 11, The barrel cortex of rodents (Jones EG Diamond IT, eds), pp 1-76. New York: Plenum).

Rorig B, Sutor B (1996) Serotonin regulates gap junction coupling in the developing rat somatosensory cortex. Eur J Neurosci 8:1685-1695.

Salichon N, Gaspar P, Upton AL, Picaud S, Hanoun N, Hamon M, De Maeyer E, Murphy DL, Lesch KP, Hen R, Seif I (2001) Excessive activation of serotonin (5-HT) $1 \mathrm{~B}$ receptors disrupts the formation of sensory maps in monoamine oxidase A and 5-HT transporter knockout mice. J Neurosci 21:884-896.

Shuey DL, Sadler TW, Lauder JM (1992) Serotonin as a regulator of craniofacial morphogenesis: site specific malformations following exposure to serotonin uptake inhibitors. Teratology 46:367-378.

Sikich L, Hickok JM, Todd RD (1990) $5 \mathrm{HT}_{1 \mathrm{~A}}$ receptors control neurite branching during development. Dev Brain Res 56:269-274.

Sultzer D, Chen TK, Lau YY, Kristensen H, Rayport S, Ewing AG (1995) Amphetamine redistributes dopamine from synaptic vesicles to the cytosol and promotes reverse transport. J Neurosci 15:4102-4108.

Szatkowski M, Barbour B, Attwell D (1990) Nonvesicular release of glutamate from glial cells by reversed electrogenic glutamate uptake. Nature 348:443-446. 
Takahashi N, Miner LL, Sora I, Ujike H, Revay RS, Kostic V, JacksonLewis V, Przedborski S, Uhl GR (1997) VMAT2 knockout mice: heterozygotes display reduced amphetamine-conditioned reward, enhanced amphetamine locomotion, and enhanced MPTP toxicity. Proc Natl Acad Sci USA 94:9938-9943.

Tamura K, Kanzaki T, Saito Y, Otabe M, Saito Y, Morisaki N (1997) Serotonin (5-hydroxytryptamine, 5-HT) enhances migration of rat aortic smooth muscle cells through 5-HT2 receptors. Atherosclerosis 132:139-143

Vongdokmai R (1980) Effect of protein malnutrition on development of mouse cortical barrels. J Comp Neurol 191:283-294.

Wang YM, Gainetdinov RR, Fumagalli F, Xu F, Jones SR, Bock CB, Miller GW, Wightman RM, Caron MG (1997) Knockout of the vesicular monoamine transporter 2 gene results in neonatal death and supersensitivity to cocaine and amphetamine. Neuron 19:1285-1296.

White EL (1979) Thalamocortical synaptic relations: a review with emphasis on the projections of specific thalamic nuclei to the primary sensory areas of the neocortex. Brain Res Rev 1:275-311.

Wong-Riley MTT, Welt C (1980) Histochemical changes in cytochrome oxidase of cortical barrels after vibrissal removal in neonatal and adult mice. Proc Natl Acad Sci USA 77:2333-2337.

Woolsey TA, Wann JR (1976) Areal changes in mouse cortical barrels following vibrissal damage at different postnatal ages. J Comp Neurol 170:53-66.

Yan W, Wilson CC, Haring JH (1997) Effects of neonatal serotonin depletion on the development of rat dentate granule cells. Dev Brain Res 98:177-184.

Yavarone MS, Shuey DL, Tamir H, Sadler TW, Lauder JM (1993) Serotonin and cardiac morphogenesis in the mouse embryo. Teratology 47:573-584.

Young-Davies CL, Bennett-Clarke CA, Lane RD, Rhoades RW (2000) Selective facilitation of the serotonin $n_{1 \mathrm{~B}}$ receptor causes disorganization of thalamic afferents and barrels in somatosensory cortex of rat. J Comp Neurol 425:130-138.

Zimmerman EF, Clark RL, Ganguli S, Venkatasubramanian K (1983) Serotonin regulation of palatal cell motility. J Craniofac Genet Dev Biol 3:371-385. 